\title{
The Effectiveness of Goat Milk to Increase the Volume of Breast Milk and Protein Content among Lactating Women: Randomized Controlled Trial Evidence
}

\author{
Prita Alvina Reviana'), Yulia Lanti Retno Dewi²), Vitri Widyaningsih²) \\ ${ }^{1)}$ Masters Program in Public Health, Universitas Sebelas Maret \\ 2) Faculty of Medicine, Universitas Sebelas Maret
}

\begin{abstract}
Background: Breast milk is a natural food to fulfill the nutritional needs of infants during the first 6 months of life. Nutrition is one of the factors that influence milk production. Protein is one of the most important nutrient factors needed by nursing mothers to increase milk production. This study aimed to analyze the effectiveness of giving goat milk to increase breast milk production. Subject and Method: A randomized controlled trial (RCT) was conducted in Madiun, East Java, in October 2019. A sample of 100 lactating mothers who had infants aged 1-3 months was selected by purposive sampling and divided into 2 groups. The dependent variables were an increase in milk production and protein intake. The independent variable was the effectiveness of giving goat milk. The data were collected by observation and 24-hour food recall sheets. The data were analyzed by $t$ test run on Stata 13 program.

Results: After having goat milk, the average of breast milk production in the intervention group $(\mathrm{Mean}=121.5 ; \mathrm{SD}=12.81)$ was higher than in the control group $(\mathrm{Mean}=97.06 ; \mathrm{SD}=13.59),(\mathrm{ES}=$ $0.81 ; \mathrm{p}<0.001)$. Protein intake after having goat milk was higher in the intervention group (Mean= 92.60; $\mathrm{SD}=4.54)$ than control group (Mean 83.36; $\mathrm{SD}=4.26),(\mathrm{ES}=2.10 ; \mathrm{p}<0.001)$.

Conclusion: Goat milk is effective for increasing milk production and protein intake in lactating mothers.
\end{abstract}

Keywords: goat milk, breast milk, protein

\section{Correspondence:}

Prita Alvina Reviana, Masters Program in Public Health, Universitas Sebelas Maret, Jl. Ir. Sutami 36A, Surakarta, Central Java, Indonesia. Email: pritasessy@gmail.com. Mobile: +6282334673976

\section{BACKGROUND}

Children are the next generation of the nation, so they should be given the best nutrition at the beginning of their lives. Breast milk (ASI) is the main natural food for newborns, because breast milk can fulfill the baby's needs for baby's energy and nutrition during the first 4-6 months of his/her life, so as to achieve optimal growth and development (Anggraini et al., 2017).

Breastfeeding for infants is expected to be able to create the achievement of the 3rd Sustainable Development Goals (SDGs), whivh is to stop infant and toddler mortality in 2030, with all countries trying to reduce neonatal mortality at least until
12 per 1,000 live births. According to the World Health Organization (WHO) and the United Nations Childrens Fund (UNICEF), it is recommended that mothers breastfeed their babies within the first hour after delivery and continue until the age of the first 6 months of the baby's life (Felly, 2018).

Coverage of exclusive breastfeeding in Madiun City in 2017 was 901 infants (70.5\%) out of 1,278 babies examined. This is still below the target of $80 \%$ of exclusive breastfeeding coverage (Madiun Health Profile, 2018).

The smooth production of breast milk is affected by many factors such as the nutritional status of the puerperal mother, 
frequency of breastfeeding, maternal age, parity, frequent breastfeeding, stress, acute illness, smoking, alcohol consumption, breast care and use of contraceptives (Yanti et al., 2018). Breastfeeding in the first 3 months is very important for nursing mothers (Atika et al., 2018). The amount of milk produced is enough for the baby, so the mother will also do exclusive breastfeeding in the following month (Sattari et al., 2019).

Goat milk as a source of good protein nutrition (Jasny et al., 2019). There are differences that cause goat milk has good characteristics (Krug et al., 2018). Goat's milk is whiter than cow's milk because goat's milk does not contain carotene which causes a slightly yellowish color. Goat milk fat has easier to digest properties than cow's milk, because the glubula diameter of goat milk fat is smaller in diameter (Hageman et al., 2019). Protein from goat's milk is easier to digest and more efficient at absorbing its amino acids because the casein size in goat milk is smaller (Wang et al., 2019).

Drinking goat's milk regularly will help postpartum mothers to launch breast milk. A cup of goat's milk has 33 percent more calcium compared to cow's milk. This content is thought to be one of the supporting substances of breast milk production (Zenebe et al., 2018).

Based on preliminary research by doing interviews to 12 breastfeeding mothers conducted at 4 Independent Midwife Practice clinics in Madiun, 7 mothers gave additional formula milk to their babies because of the low production of breast milk. The author was interested in conducting experimental research on the effecttiveness of giving goat milk to nursing mothers to increase breast milk production.

\section{SUBJECTS AND METHOD \\ 1. Study Design \\ This type of study was an experimental ran- domized controlled trial design. Data col- lection was carried out in 3 places of inde- pendent/private practice Midwives in Madiun, in October 2019.}

\section{Population and Sample}

The population used in this study was nursing mothers for 1-3 months. The total sample were 100 research subjects. Sampling was using random sampling technique and included in 2 groups, namely intervention and control by using purposive sampling techniques in the area of Madiun, East Java.

\section{Study Variables}

The dependent variables were breast milk and protein volumes. The independent variable was goat milk.

\section{Operational Definition of Variables} Goat milk administration was an activity of giving pure goat milk in the form of pure powder by 1 box containing 10 sachets weighing $20 \mathrm{~g} / \mathrm{sachets}$, which would be consumed by 1 sachet per day regularly by brewing 150 cc of warm water without adding sugar. Given to 50 research subjects included in the intervention group, while 50 control subjects were not given goat milk. The measuring instrument used was an observation sheet. The measurement scale was categorical.

Frequency of breastfeeding was the number of times a mother breastfeeding or emptying her breast milk within 1 day, by pumping or breastfeeding directly. The measuring instrument was observation sheet. The measurement scale was continous.

Duration of breastfeeding was the length of time the mother breastfeeding from the time the baby is born until the time of the study in units of months. Measurement instrument was observation 
sheet. The measurement scale was continous.

Amount of breastmilk was the amount of milk produced by the mother in a single pumping. The tool for pumping breast milk is an electric breast pump. The measuring instrument was a chemical measuring cup. The amount of breastmilk would be recorded on the observation sheet. The measurement scale used was a continuous scale.

The amount of protein intake was the amount of protein consumed by nursing mothers for 1 full day. Measuring instruments used 24-hour food recall sheets, tables of food consumed by mothers would be processed with the application of the 2007 survey nutrition. The measurement scale was continous.

\section{Data analysis}

Univariate data analysis was grouped according to the data scale. Bivariate analysis used a two-group t test. Data was processed by using the Stata 13 program.

\section{Study Ethic}

This study was conducted based on research ethics, namely informed consent, anonymity, confidentiality, and ethical eligibility. Ethics permission in this study was obtained from the Health Research Ethics Commission of Dr. Moewardi Hospital, Surakarta, Indonesia, No. 1.187/X/HREC/2019.

\section{RESULTS}

\section{Univariate Analysis}

Table 1 showed that the sample of breastfeeding mothers studied had on average been breastfeeding for 2 months. Frequency of breastfeeding per day on average of 8.5 times/day.

Table 1. Sample characteristics (continous data)

\begin{tabular}{lccccc}
\hline \multicolumn{1}{c}{ Characteristics } & n & Mean & SD & Min. & Max. \\
\hline Parity & 100 & 2.58 & 0.67 & 2 & 4 \\
Duration of breastfeeding (month) & 100 & 2.12 & 0.79 & 1 & 3 \\
Frequency of breastfeeding (per day) & 100 & 8.46 & 0.50 & 8 & 9 \\
Protein before intervention (g) & 100 & 75.97 & 3.19 & 70.21 & 80.55 \\
Protein after intervention (g) & 100 & 87.98 & 6.38 & 75.21 & 99.73 \\
Breast milk before intervention (ml) & 100 & 86.21 & 13.19 & 65.20 & 110 \\
Breast milkafter intervention (ml) & 100 & 109.28 & 18.19 & 75.70 & 146 \\
\hline
\end{tabular}

Table 2 showed that the sample of breastfeeding mothers studied was 20 - 35 years old on average. Education was generally middle or high school. About half of all breastfeeding mothers studied worked at home as housewives.

Table 2. Characteristics of research subjects with categorical data

\begin{tabular}{lcc}
\hline \multicolumn{1}{c}{ Characteristics } & n & \% \\
\hline Age & & 0 \\
$<$ 20 years old & 0 & 90 \\
20 - 35 years old & 90 & 10 \\
$>$ 35 years old & 10 & 6 \\
Education & & 76 \\
ES & 6 & 18 \\
JHS, HS & 76 & \\
College & 18 & 54 \\
Employment & & 32 \\
Housewives & 54 & 14 \\
Entrepreneur & 32 & \\
Civil Servant & 14 & \\
\hline
\end{tabular}




\section{Bivariate Analysis}

Table 3. $t$ test differences in the mean of the intervention and control groups before and after the intervention

\begin{tabular}{|c|c|c|c|c|c|}
\hline Variable Group & $\mathbf{n}$ & Mean & SD & $\mathbf{p}$ & Effect Size \\
\hline \multicolumn{6}{|c|}{$\begin{array}{l}\text { The volume of breast milk before } \\
\text { intervention }\end{array}$} \\
\hline Intervention & 50 & $87 \cdot 31$ & 12.81 & 0.404 & 0.17 \\
\hline Control & 50 & 85.10 & 13.59 & & \\
\hline \multicolumn{6}{|c|}{$\begin{array}{l}\text { The volume of breast milk after } \\
\text { intervention }\end{array}$} \\
\hline Intervention & 50 & 121.5 & 12.82 & $<0.001$ & 1.81 \\
\hline Control & 50 & 97.06 & 14.13 & & \\
\hline \multicolumn{6}{|c|}{ Protein before intervention } \\
\hline Intervention & 50 & $75 \cdot 58$ & 3.29 & 0.222 & -0.24 \\
\hline Control & 50 & 76.36 & 3.08 & & \\
\hline \multicolumn{6}{|c|}{ Protein after intervention } \\
\hline Intervention & 50 & 92.60 & 4.54 & $<0.001$ & 2.10 \\
\hline Control & 50 & 83.36 & 4.26 & & \\
\hline
\end{tabular}

Table 3 showed that there was no statistically significant difference in the volume of breast milk before the intervention $(\mathrm{p}=0.404)$. The findings showed that randomization succeeded in making the two groups comparable in various variables, including the volume of breast milk before the intervention. With randomization, each breastfeeding mother in the sample has the same probability of being selected into the goat milk group and the control group.

After the intervention, the average volume of breastfeeding of breastfeeding mothers in the intervention groups was higher $(\mathrm{Mean}=121.5 ; \mathrm{SD}=12.81)$ than in the control group (Mean= 97.06; $\mathrm{SD}=$ 13.59) and the difference was statistically significant $(\mathrm{p}<0.001)$. Table 3 also showed that giving goat milk gave a quite large Effect Size $(E S=0.81)$. So it was concluded that the provision of goat milk was effective for increasing the volume of breast milk for nursing mothers.

There was no statistically significant difference in protein intake before the intervention $(\mathrm{p}=$ 0.222). The findings showed that successful randomization made the two groups comparable on various variables, including protein intake before the intervention. By randomization, each breastfeeding mother in the sample had the same probability of being selected into the goat milk group and the control group.

After the intervention, the average protein intake of breastfeeding mothers in the intervention group was higher (Mean= 92.60; $\mathrm{SD}=4.54)$ than in the control group (Mean 83.36; $\mathrm{SD}=4.26$ ) and the difference was statistically significant $(\mathrm{p}<0.001)$. Table 3 also showed that giving goat milk gives a fairly large Effect Size $(E S=2.10)$. So it was concluded that giving goat milk was effective for increasing protein intake of nursing mothers.

\section{DISCUSSIONS}

1. Effectiveness of giving goat milk to breast milk production for nursing mothers

The analysis showed that breastfeeding mothers who consumed goat milk for 10 consecutive days had a statistically significant increase in breast milk production. The result of this study was in line with 
study that state that regular consumption of goat milk for 7-10 days will increase breast milk production (Pazolla et al., 2019). Other studies suggest that regular goat milk can increase breast milk production by 15 $\mathrm{ml} \mathrm{-} 30 \mathrm{ml}$ in every pumping (Garovic, 2018).

Goat milk is milk derived from types of dairy goats (Wang et al., 2019). Etawa goat milk has a composition that is richer than other types of goat milk, and has no pungent and fishy odor (Ratya et al., 2017). Goat milk was used as an alternative nutritional intake for children who were allergic to cow's milk (Lurette et al., 2018). Consuming goat milk regularly would help pregnant women to have good breast milk, so that after the fetus was born, breast milk would run smoothly. Sufficient volume of breast milk would lead to exclusive breastfeeding behavior (Atika et al., 2018). A cup of goat's milk has $33 \%$ more nutrients compared to cow's milk (Huang et al., 2018). Goat milk is herbal, and it can stimulate the hormone prolactin gradually and would get maximum results after 7-10 times consumption (Felly, 2018).

Consuming goat's milk regularly for 10 days would increase breast milk production, so the baby's daily milk consumption needs can be fulfilled and the baby's immunity would be formed properly due to the application of exclusive breastfeeding.

2. The effectiveness of giving goat milk to the protein intake of nursing mothers

The results of this study indicated that goat milk was effective in increasing the protein intake of nursing mothers which was statistically significant. The result of this study was in line with study done by Rupp et al., (2018), which stated that regular consumption of goat milk can help the synthesis of the hormones prolactin and oxytocin, so as to increase milk production and expendi- ture. Another study stated that by consuming goat milk, it can increase appetite because in goat milk, there is a greater vitamin B1 content than cow's milk (Ziarnoet al., 2019).

Protein is an important nutrient that is needed in building and repairing various tissues in the body (McRae, 2019). Protein also plays an important role in the growth and development of infants in the early days of their lives (Rosartio et al., 2017). Protein is also much needed to help recovery after pregnancy and childbirth (Yantinet et al., 2018). Types of foods that contain protein are meat, chicken, fish and seafood, eggs, cheese, milk, yogurt, and other protein sources (Puspitarini, 2018). Goat milk protein has small particles that are easily absorbed by the body (Ziarno et al., 2019).

Goat milk contained protein with small particles so that it was easily absorbed by the body while meeting the daily protein needs of nursing mothers.

\begin{tabular}{l} 
AUTHOR CONTRIBUTIONS \\
\hline Prita Alvina Reviana as the main researcher \\
has roles to carry out the study, the \\
formulation of study articles, and data \\
processing. Yulia Lanti Retno Dewi has \\
roles in arranging the background and \\
discussion of the study. Vitri Widyaningsih \\
has roles in discussing the methodology \\
and study results
\end{tabular}

FUNDING AND SPONSORSHIP There was no external funding.

\section{CONFLICT OF INTEREST}

There was no conflict of interest.

\section{ACKNOWLEDGEMENT}

Acknowledgments were conveyed by author to the Regional Government of Madiun who had given permission for conducting the 
study. Thank you to all nursing mothers who have been willing and cooperative to be the subject of research.

\section{REFERENCE}

Angriani R, Sudaryati E, Lubis Z (2017). Relationship of frequency of breastfeeding with the smooth production of breast milk of post-partum mothers in the work area of South Peusangan Public Health Center, Bireuen Regency, Aceh Province. J Muara Sains, Teknologi Kedokteran, dan Ilmu Kesehat, 2(1): 299-304. https:// jour-nal.untar. ac.id/index.php/jmistki/article/down load/2110/1408

Atika Z, Salimo H, Dewi YLR (2018). Multilevel analysis on the determinants of exclusive breastfeeding at Gunung Anyar Community Health Center, Surabaya, Indonesia. J Matern Child Health, 3(3): 176-183. https://doi.org/10.26911/thejmch.2018.03.03.02

Dinkes Jatim (2018). East Java Province Health Profile in 2017. Surabaya: Dinkes Jatim. https://www.depkes.go.id/resources/download/profil/PROFIL _KES_PROVINSI_2017/15_Jatim_2 017.pdf

Dinkes Kota Madiun (2018). Madiun City Health Profile in 2017. Madiun: Dinkes Kota Madiun. http://dinkes.madiunkota.go.id/wp-content/uploads/2018/10/PROFIL-KESEHATAN-2017.pdf

Felly E (2018). Factors that influence exclusive breastfeeding. J Penelit Kesehat, 9(2):101-113. https://ejournal.unsrat.ac.id/index.php/eclinic/article/downl oad/18524/18052

Garovic VD (2018). The consumption of goat milk in nursing mothers. Food Nutrition, 59(3):555-557. doi: 10.1161 /hypertensionaha .111 .184192
Hageman JHJ, Danielsen M, Nieuwenhuize AG, Feitsma AL, Dalsgaard TK (2019). Comparison of bovine milk fat and vegetable fat for infant formula: Implications for infant health. Int Dairy J, 92:37-49. doi: 10.1016/j.idairyj.2019.01 .005

Huang Y, Ouyang YQ, Redding SR (2018). Previous breastfeeding experience and its influence on breastfeeding outcomes in subsequent births: A systematic review. Women and Birth. doi: 10.1016 /j.wombi .2018.09.003

Jasny E, Amor H, Baali A (2019). Mother's knowledge and intentions of breastfeeding in Marrakech, Morocco. Arch Pediatr. doi: 10.1016/j.arcped.2019.05.007

Kemenkes (2017). Indonesian Health Profile of 2016. Jakarta: Kemenkes. https://www.depkes.go.id/resources/download/pusdatin/profil-kesehatan-indonesia/Profil-Kesehatan-Indonesia-2016.pdf

Krug C, Morin P-A, Lacasse P (2018). A randomized controlled trial on the effect of incomplete milking during the first 5 days in milk on culling hazard and on milk production and composition of dairy goat. J Dairy Sci, 101(5):4367-4377. doi: 10.3168/jds.2017-14021

Lurette A, De Boissieu C, Morin E, Hassoun $\mathrm{P}$, Moulin $\mathrm{CH}$ (2018). Improved management to limit milk production losses resulting from the transition to once-a-day milking in dairy goat. Small Rumin Res, 165(6):8-16. doi: 10.1016/ j.smallrumres.2018.06.07

McRae MJ (2019). Exclusive breastfeeding, 24-hour rooming-in, and the importance of women's informed choices. Nurs Womens Health. 20 (8):1-7. doi: 10.1016/j.nwh.2019.05.003 
Pazzola M, Stocco G, Dettori ML, Bittante G, Vacca GM (2018). Effectiveness of soy milk and goat's milk for nursing mothers. J Dairy Sci, 102(5):39473955. doi: 10.3168/jds.2018-15397

Puspitarini OR, Herbani M (2018). Protein content, fat content and non-fat solid pasteurized goat milk in refrigerator storage. J Apl Teknol Pangan, 7(1):1214. doi: 10.17728/jatp. 2162.

Ratya N, Taufik E, Arief I (2017). Chemical, physical and microbiological characteristics of Ettawa crossbreed milk in Bogor. J Ilmu Produksi dan Teknol Has Peternak, 05(1):1-4. doi: 10. 12823/jtekno.2017-1394

Rosartio R, Suranindyah Y, Bintara S, Ismaya I (2017). Production and composition of Ettawa crossbreed milk in the highlands and lowlands of Yogyakarta. Bul Peternak, 39(3):180.doi: 10.21059/bulle-tinternak.v39i3.7986

Rupp R, Huau C, Caillat H (2019). Dairy goat saenen for the fulfillment of nutritional nursing mother. J Dairy Sci, 102 (6): 5242-5253.doi: $10.3168 / j \mathrm{ds}-$ .2018-15664

Sattari M, Serwint JR, Levine DM (2019). Maternal implications of breastfeeding: a review for the internist. Am $\mathrm{J}$ Med. doi: 10.1016/j.amjmed.2019.02.021

Sinta P, Salimo H, Pamungkasari P (2017). Multilevel analysis on the biosocial and economic Determinants of Exclusive Breastfeeding. J Matern Child Health, 2(4): 356-370. https://doi.org/10.26911/thejmch.2017.02.04.06

Wang Y, Zhang Y, Chi X (2019). International Immunopharmacology Antiinflammatory mechanism of ginsenoside Rg1: proteomic analysis of milk from goats with mastitis induced with lipopolysaccharide. Immunophar ma, 12(2):382-391. doi: $10.1016 /$ j.in timp. 2019.03.048

Yanti HF, Yohanna WS, Nurida E (2018). The smooth production of breast milk in post-partum mothers is seen from the initiation of early breastfeeding and baby's suction. J AisyahJ Ilmu Kesehat,3(1): 39. doi: 10.30604/ jika. v3i1.74

Zenebe T, Ahmed N, Kabeta T, Kebede G, Medicine V, Box PO (2017). Review on medicinal and nutritional values of goat milk, 3(3):30-39. doi: 10.5829/ idosi.ajn .2014.3.3.93210

Ziarno M, Dmytrów I, Balejko J (2017). Short communication: Short communication: Effect of the addition of Bifidobacterium monocultures on the physical, chemical, and sensory characteristics of fermented goat milk. J Dairy Sci, 100(9): 6972-6979. doi: 10.3168/jds.2 017-12818 